\title{
Christian Youth Leadership in a Distruptive Era (Research on Gmim Bukit Zaitunranomuut)
}

\author{
Aljuanika Ertamaya Ering ${ }^{1}$, Shanti N.Ch Ruata ${ }^{2}$, Melissa M.F Waturandang ${ }^{3}$, \\ Mercy Waney ${ }^{4}$, Yunita Sumakul ${ }^{5}$, Mariana L. M Lausan ${ }^{6}$ \\ Institut Agama Kristen Negeri Manado \\ ikaering12@gmail.com¹, shantiruata@iakn-manado.ac.id², melissawaturandang@iakn-manado.ac.id², \\ mercywaney79@gmail.com ${ }^{4}$,yunita@iakn-manado.ac.id ${ }^{5}$,marianalausan@gmail.com6

\begin{abstract}
Christian youth leadership began to experience disruption along with technological developments. This study aims to describe how the leadership of Christian youth in the GMIM Bukit ZaitunRanomuut congregation, describes what efforts were made by young Christians as the next generation of the church in maintaining leadership within the GMIM Bukit ZaitunRanomuut congregation. The data in this study were observed and collected through interviews with young people at the GMIM Bukit ZaitunRanomuut, after which it was analyzed. It was found that the youth leadership of GMIM Bukit ZaitunRanomuut assumed that the leader was only limited to someone who led a group of people such as the youth elder and the youth commission in the GMIM Bukit ZaitunRanomuut congregation. Efforts are being made to continue to give themselves in youth fellowship and youth leadership training. For this reason, Christian youth, as successors to the church, must realize that each person is a leader who leads himself, so he must try to equip himself with various youth training and fellowships to have an impact on others.
\end{abstract}

Keywords: Christian Youth, Christian Youth Leadership, Distruptive Era.

\section{Introduction}

The church is a forum for the gathering of Christians in a fellowship. Christians understand that the church is not an existing building but a people allied in it. In the church environment, youth is one part of the church apart from mothers, fathers, youth and children. Church youth are the church's successors who will be the future leaders of the church.

Youth is vulnerable to various curiosity. Curiosity is an important thing and becomes an inseparable part for a young man to find his true identity. But sometimes young people do things that refer to negative things, so that often young people fall into negative things. among others, prefer to relax with friends rather than allied worship in a youth fellowship, come home late on Saturday night so do not enter the church, prefer status updates on social media to insinuate people, refuse when appointed to lead worship, do not dare to appear in front. Even this was found in young people at GMIM Bukit ZaitunRanomuut.

As the successor to the youth church, they are prepared to be church leaders who will carry the spear of church services in the future. Youth should have high enthusiasm in service because youth are productive people who have high creativity. A person is said to be a leader not only when he is given a special responsibility to lead a group of people. As Susanto (2005: 7) has said, each person is a leader for himself. So as part of the fellowship, the youth must be a leader who can bring himself in a good direction. 
With the phenomena that occur in Christian youth GMIM Bukit ZaitunRanomuut above, the researchers formulated the problem in this study, namely: (1). How is the leadership of Christian youth in GMIM Bukit ZaitunRanomuut congregation? (2). What are the efforts made by Christian youth as the next generation of the church in maintaining leadership within the GMIM Bukit ZaitunRanomuut congregation?

The research objectives are: (1). To describe how the leadership of Christian youth in the GMIM Bukit Zaitun University Ranomuut, (2). To describe the efforts made by Christian youth as the next generation of the church in maintaining leadership in the GMIM Bukit ZaitunRanomuut congregation.

\subsection{Christian Leaders and Leadership}

The role of the leader is as a servant and an example (Dinnen 2013: 4). Even this is not separated from a young man who is said to be a leader. When becoming a servant of course a young man must be able to be someone who wants to give themselves in service so that his example can be seen by people and have an impact on others. In simple terms the role of this leader can be seen when a young man wants to be present in a worship meeting both within the youth organization and the environment of the church. This simple role is not difficult to do if a young man as a leader wants to lead himself in a good direction.

A leader's vision is something that must be upheld in carrying out every activity of his life. As revealed by Jogiyanto (2010: 18), a leader must have a vision that is a critical success factor because it has the benefit of enabling leaders to dream big things, cause continuity in service movement, determine direction and goals, increase mutual interest and commitment, produce changes that are commonly accepted, function as a filter to filter the various opportunities available, provide encouragement / enthusiasm, create self-confidence, cause loyalty, create work productivity. The benefits of having a clear vision naturally lead to a young person being good first so that it can have an impact on others.

The absence of effective leadership will result in the church lacking quality leaders in the future (Prihanto 2018: 1). A leader will never be free from difficulties or problems that often result in the slacking of the spirit of leadership, but as a leader, the youth must suffice in all circumstances, continue to never give up, dare to accept the worst risks and rely on God as revealed by Jogiyanto $(2010: 31)$. So that it can form the quality of the character of a reliable and successful leader according to Boestam (2013: 13), namely

a) Patience, a calm endurance, not uneasy, not worried, remain standing firm in the face of opposition, pressure and difficulties that exist.

b) High fighting power, when someone gives up easily will easily lose, but when someone struggles without stopping then he has a chance to win

c) Love and compassion for humans, love the people they lead and bring people to the destination.

d) Consistency, fixed, firm, sturdy, solid, unchanging, consistent. (Can maintain / maintain something good.

e) Longing / intimacy with God, closeness to God, spending time with God.

f) Meek, gentle is needed in correcting people who commit violations.

g) Easy to teach, a person leaders must be able to take advice from others and must be able to learn from others.

h) Leader's skills, the skills of a leader will bring the person he leads to the right path.

i) Doing priority things, there are many things that will met by a leader, the leader must be able to determine what he must do first. 
George Barna (Boestam 2013: 51) leadership is the process of motivating, mobilizing, equipping and directing people to pursue a vision from God that is shared by a group with a passionately planned. From this we can see that this leadership comes from oneself first then can influence others. The life of youth leadership must certainly continue to be equipped so that the leadership process does not stop but continues to grow until it produces fruit. According to MacArthur (2009: 160) The principle of leadership is, trustworthy, take initiative, make good decisions, speak in an authoritative manner, strengthen others, be optimistic and enthusiastic, never compromise on things that are absolute, focus attention on targets, not obstacles, strengthen and empower others through his life model, foster loyalty to his followers, have empathy for others, keep his conscience clear, firm and clear, know when to change his mind, not abuse his authority, not abandon his role when there are challenges from others, believe in his calling, know his limitations, know when to change his mind, not abuse his authority, not abandon his role when there are challenges from others, be sure of his calling, know his limitations , must be resilient, have passion, brave soul, must be observant, have self-discipline, always look powerful, know how to share tasks with others, like Christ.

\subsection{Christian Youth Leadership in the Distruptive Era}

Christian youth today continue to face challenges through technological developments that cannot be stopped. According to Cole (2016: 29) Christian leaders today are accountable to God. This illustrates that Christian leaders certainly do everything good that can have a positive impact on him even for others.

According to Sitepu (2019: 1) the leadership style adopted by church leaders has not been effective because it has not been able to motivate subordinates to achieve their best performance. Especially in this distracting era.

The distorted era should not be an obstacle for Christian leaders to continue to bring themselves in the right direction. Disruption in the form of technology must strengthen Christian leaders rather than disrupt and destroy existing leadership. Leaders are required to have a wide range of insights and knowledge, meaning there must be awareness to always want to learn, Susanto (2010: 7). In growing leadership, if leaders are not planted in good soil, no matter how much effort, resources, and programs that we invest from outside, eventually the seeds of leadership will not bear fruit. (Cole, 2016: 145). In other words, when leadership has grown and accustomed to the right understanding, leadership will never be disturbed and produce good fruit.

Most people think that leadership will only apply when there is a group of people or there is an organization formed and there are leaders inside. Leadership is not bound to the organizational chart, but in one word, influence. Jesus worked entirely outside the formal organizational structure of his day, but he was a strong leader. Cole (2016: 95). Basically, Jesus worked in ancient times without any organization he led, but He worked extraordinarily so that many who were called to believe believed in following him. The influence that God does is certainly very big because he exemplifies things that start from himself.

Leadership imbued with Christian faith requires the establishment and maturity of the leader's attitude to develop uniqueness, spirit and grace. The great Christian faith through the attitude of enthusiasm as exemplified by Jesus will be a reflection of others when that faith is really implemented in human life.

Christian youth as leaders to be able to survive in this distrustful era require the basic needs of self-integrity. Self-integrity can be seen from one's loyalty to duties and responsibilities even though the work faced is small, because with his loyalty to small cases 
will make him able to carry out large cases (Susanto, 2010:15). The distracting era requires an awareness that is always new to become someone who can survive in the midst of technological developments for the sake of personal interests to become a better person. Study and continue learning without stopping. The basic beginning of developing interests is to start with a new awareness (Pue, 2014: 21).

\section{Method}

\subsection{Research Approach}

This research uses descriptive qualitative research. The research method with a qualitative approach is called naturalistic inquiry or commonly also called the naturalistic approach which means that the data obtained is natural and relevant to the situation and condition of the subject and object that are the focus of research (Moleong 2001: 16). This study describes things that occur naturally.

\subsection{Participant}

Participants in this study were 4 young people from GMIM Bukit Zaituns Ranomuut.

\subsection{Data Collection Procedure}

Data collection in this study uses namely:

a) Observation. According to Sugiyono (2010: 203), observation is a process that is complex, deliberate, and carried out systematically, planned, directed, at a goal by observing and covering phenomena or groups of people in the complex of daily life to get the information needed to continue research. Observations made by researchers are to get a natural and clear picture and observe all activities that occur directly. Through observation researchers try to listen, observe and try to get answers to the problems to be studied. In this observation the researcher was present directly at the research site, GMIM Bukit ZaitunsRanomuut.

b) Interview. To collect research data, the researchers used interviews where researchers and participants carried out questions and answers to obtain specific goals. The type of interview used is an informal interview interview. According to Moleng (1991: 136), the question asked depends on the interviewer himself, so it depends on his spontaneity in asking questions to the interviewee. The interviewer's relationship with the interviewee is in a normal, normal atmosphere, while the questions and answers run like normal conversation in daily life. With these guidelines make it easier for researchers to get more other findings related to what will be studied. This interview is intended to find out deeply and naturally.

\subsection{Research Data Analysis}

Analyzing data is an attempt to search for data systematically and structured based on the notes when conducting observations and interviews in increasing the understanding of 
researchers about the research subject itself. In this study researchers used descriptive data analysis where the things done were as follows:

a) Data collection, the data collection process is the result of data collection obtained from the field. Both obtained from observations or observations or interviews. The data collected is usually still in the form of raw data that has not been processed and reviewed so it is necessary to choose which data is important.

b) Data reduction, in this process it is intended to obtain data in a more focused and concentrated way. Because the data is too broad and many will only give difficulties when looking for a clear and precise picture. This process is a process of focusing on simplification and transformation of the amount of data obtained in the field.

c) Data display, the results of the reduction process that allows the conclusion based on interrelated facts.

d) Draw conclusions, get the final results of the research carried out. (Moleong, 1991: 140).

\section{Result and Discussion}

Youth awareness of leadership begins with his contribution by carrying himself guided by his own leadership. The awareness of leadership in a young person is needed by the church because youth are the next generation of the church. Based on observations made on the three subjects, it was found that youth still experienced difficulties in their leadership, especially when carrying out church activities even in youth fellowship. For example when young people are scheduled to bring praise in church buildings, they tend not to want to come up front when giving praise in worship meetings. Youth tend to be more willing to gather behind. Even their delay when entering the church often makes young people just sit outside the church. Whereas young people who attend before worship starts tend not to sit in front.

JP revealed that he still lacked confidence when appointed to lead the worship meeting, he added that it took a long time for him to prepare to lead the worship, even though in reality JP was a youth commission. According to NT the leadership is only by someone who has a group of people led by him, such as the example of a young elder. This is also in line with MW's statement that he is only limited to youth members. The duties and responsibilities of leadership lie with the youth elder and the commission.

Realities like this are still far from understanding the existing Christian youth. This awareness needs to be developed and developed for young people because starting from where the habituation of positive things begins. The courage of a Christian youth who still lacks need to be trained continuously. because if this is allowed then the future leadership will experience difficulties. In the future the church will experience a leadership crisis.

The role of Christian youth is trained to start in small matters concerning his own personality. Even this is driven by the motivation of parents to teach their children at home. Parents have more time together with their children because in youth services youth fellowship is only limited to 2 worship meetings each week.

But according to JP, one of the factors that also causes youth to not be active in service is that youth has a lot of activities. "Some are working and some are studying," continued JP. The work done by most young people is far away and starts on Monday to Friday, and some even work until Saturday. This made them tired and most of them were absent from the worship meetings. 
There are so many principles and leadership that starts from the person of a young man himself. When a young person has the awareness to lead himself to a good thing, he will get used to manifesting his leadership even though his position in an organization is not owned. Someone who is able to lead himself will surely be able to influence others who live together with him

The results of interviews with JP, NT and MW revealed that the leadership activities they participated in were LKPG. In this activity they are given materials that will continue to equip them to be more able to lead themselves. According to MW, besides joining LKPG, he also participated in other leadership activities including leadership activities in adolescents. For all three leadership activities like this are not enough to make them as leaders, especially in the organizational environment. Habits that arise from oneself must continue to be strengthened.

The habit of leadership is also reflected in arts and sports activities. In arts activities such as choirs, young people are trained in how their leadership to bring themselves to be present in each exercise on time according to the schedule. Likewise in sports activities, young people are trained to be patient in competing and maintaining mutual sportsmanship.

In reality, according to NT, the implementation of institutional activities often can only make Christian youth diligently attend worship meetings. But after that they had started again not seen in worship meetings. Various kinds of disorders such as technology have become an important role that threatens the lives of young people. Because there were Christian youths who were only busy playing online games during the worship meeting. There are even Christian youths who are temporarily worshiping but are busy playing online games or busy with social media such as Facebook, Instagram, and WhatsApp.

\section{Conclusion}

From the results of the analysis it can be concluded based on the results of existing studies that:

Leadership in the GMIM Bukit Zaitun University Ranomuut only assumes that the leader is someone who has an organization to dream about. The lack of awareness of this young man often results in neglect of service especially in the church. Leadership activities carried out at GMIM Bukit ZaitunRanomuut congregation are in the fields of sports, arts, and leadership training.

Based on the results of the study put forward suggestions:

a) Awareness and understanding of youth about their leadership to themselves must continue to be improved.

b) Leadership activities must be maintained even further.

\section{References}

[1] Arifianto, S. ImplementasiMetodePenelitian "StudiKasus" denganPendekatanKualitatif.: AswajaPressindo, Yogyakarta (2016)

[2] Boestam,P.: Smart christian leadership. Andi, Yogyakarta (2013)

[3] Cole, Neil. : Organic Leadership (MemimpinsecaraAlamitepatdimanaandaberada). Andi, Yogyakarta (2016) 
[4] Dinnen, Stewart.: You Can Learn To lead(dasar dan strategi kepemimpinan yang melahirkangenerasipemimpin). Andi, Yogyakarta (2013)

[5] Jogiyanto : Menjadipemimpinunggul. Andi, Yogyakarta (2010)

[6] MacArthur, John.: Kitab kepemimpinan (26 karakter pemimpin sejati). BPK Gunung Mulia, Jakarta (2009)

[7] Moleong, Lexy, J.. MetodologiPenelitianKualitatif. RemajaRosdakarya, Bandung (1991)

[8] Pue, Carson. :Mentoring Leaders (Bimbingan jitu para pemimpin menuju pelayanan maksimal bagi kerajaan Allah). Andi, Yogyakarta (2014)

[9] Sugiyono. Memahamipenelitiankualitatif. Alfabet, Bandung (2010) 